Federal Reserve Bank of Minneapolis

\title{
QuarterlyReview
}

Winter 1983

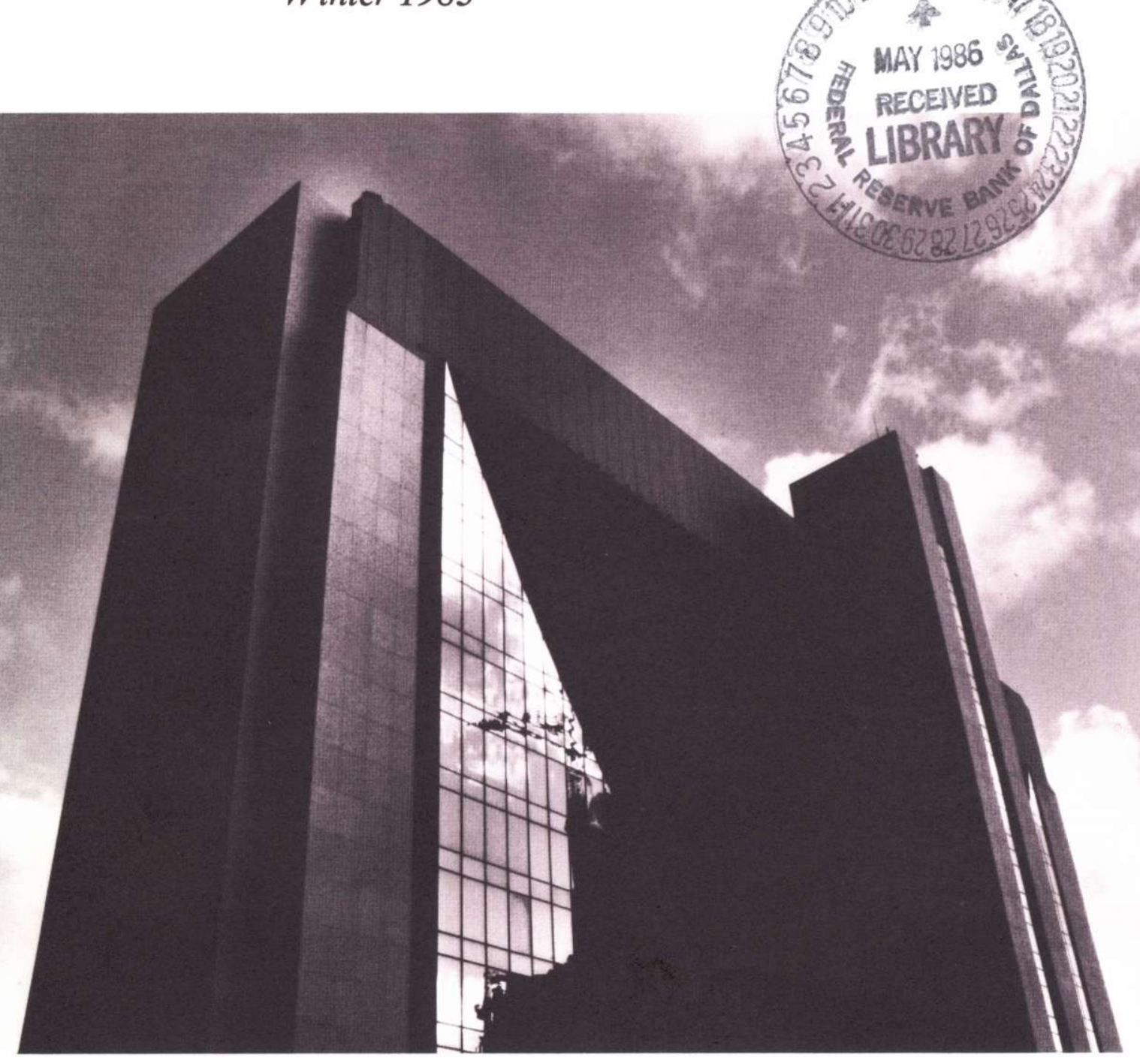

A Legal Restrictions Theory of the Demand for "Money" and the Role of Monetary Policy Neil Wallace (p. 1)

Higher Deficit Policies Lead to Higher Inflation Preston J. Miller (p. 8)

District Conditions

Recovery Likely to Be Stronger Than Expected

(p. 20) 
Federal Reserve Bank of Minneapolis Quarterly Review vol.7, No.1

This publication primarily presents economic research aimed at improving policymaking by the Federal Reserve System and other governmental authorities.

Produced in the Research Department. Edited by Richard M. Todd, Patricia Lewis, and Kathleen S. Rolfe. Graphic design by Phil Swenson and typesetting by Barbara Cahlander, Graphic Services Department.

Address requests for additional copies to the Research Department,

Federal Reserve Bank, Minneapolis, Minnesota 55480.

Articles may be reprinted if the source is credited and the Research

Department is provided with copies of reprints.

The views expressed herein are those of the authors and not necessarily those of the Federal Reserve Bank of Minneapolis or the Federal Reserve System. 


\section{Higher Deficit Policies Lead to Higher Inflation*}

Preston J. Miller

Monetary Adviser

Research Department

Federal Reserve Bank of Minneapolis

If Congress does not act, the U.S. federal budget deficit could easily exceed $\$ 200$ billion in each of the three fiscal years 1983-85. ${ }^{1}$ This budget hemorrhage would come on top of deficits averaging $\$ 76.5$ billion per year over the last three fiscal years and would make sixteen straight years the budget has been in the red. Deficits have been persistent and have been getting larger.

The divergence of the government's expenditures and revenues perhaps has been no larger than the divergence of economists' views on that policy's likely economic effects. And nowhere has the divergence of views seemed wider than on its inflationary effects.

Many economists argue that persistently higher deficits do not necessarily lead to higher inflation. (See, for example, Blinder 1982, Friedman 1981a, Grossman 1982, Hamburger and Zwick 1981, Hein 1981, Sprinkel 1981, and Weintraub 1981.) They argue that inflation results when the supply of money grows faster than the supply of goods, which in turn results when the Federal Reserve purchases too many government bonds. These economists (whom I label monetarists) thus conclude that the Federal Reserve can prevent higher deficits from causing more inflation by refusing to buy the extra government bonds that result from those deficits (that is, by refusing to monetize the deficits). As support for this view that higher deficits are not necessarily inflationary, monetarists cite numerous empirical studies which indicate weak, if any, correlation between deficits and inflation in the United States.

In this paper, I take the opposing view: Persistently higher deficits-changes in budget policy that for any given economic conditions imply higher deficits than would have occurred under previous budget policy-do indeed lead to more inflation. A theory which admits the possibility of such policy changes suggests that the changes affect inflation in three ways.

One way is by necessary monetary accommodation. Contrary to what monetarists believe, the Federal Reserve may have to monetize some of the extra debt; that may be the only way to prevent the government from becoming insolvent.

Even to the extent that the Federal Reserve does not monetize the debt, however, adjustments in the private economy to the higher deficit policy lead to more inflation, in two other ways: by crowding out and by private monetization of debt. When additional government debt is not monetized by the Federal Reserve, the debt adds to net credit demands and raises interest rates. Higher interest rates crowd out investment in plant and equipment, which reduces the rate of real growth in the economy. With the same amount of money chasing fewer goods, prices are driven up. In the financial sector, meanwhile, higher interest rates make profitable the development of new financial instruments that make government bonds more like money. These instruments allow people to hold interest-bearing

*This is a substantially revised version of a paper presented at The Economic Consequences of Government Deficits: An Economic Policy Conference, cosponsored by the Center for the Study of American Business and the Institute of Banking and Financial Markets and held at Washington University, St. Louis, Missouri, in October 1982. That paper is forthcoming in a volume of the conference proceedings.

${ }^{1}$ The Congressional Budget Office's (CBO's) baseline budget projections forfiscal years 1983-85, which are based on assumptions of no change in current laws and no change in real discretionary spending, are $\$ 194$ billion, $\$ 197$ billion, and $\$ 214$ billion, respectively. These large baseline deficits are based on the CBO's assumption of a weak economic recovery. However, even assuming a strong economic recovery over the next three years, the CBO estimates that deficits would still be $\$ 178$ billion, $\$ 155$ billion, and $\$ 162$ billion, respectively. (See U.S., Congress, CBO 1983). 
assets that are as risk-free and as useful in transactions as money is. In this way, the private sector effectively monetizes government debt that the Federal Reserve doesn't, so the inflationary effects of higher deficit policies increase.

Despite monetarists' claims, this view that higher deficit policies lead to higher inflation is supported by empirical work. Studies properly designed to capture the effects of budget policy changes show that both U.S. and international experiences are consistent with this view: a change in budget policy which results in higher deficits year-in and year-out leads to higher average inflation. Studies that do not support this view mistakenly relate isolated deficits and inflation rates instead of properly relating deficit policies and average inflation experience.

\section{How Governments Can Run Persistent Deficits}

A budget deficit occurs when spending exceeds taxes, user fees, and other explicit revenues. The simplest form of a higher deficit policy-a permanent increase in deficits-requires that spending permanently exceed revenues, but this would seem to violate the simple accounting constraint that what goes out must not exceed what comes in. That it doesn't is due to the existence of fiat debt, those government liabilities for which there are no offsetting assets. When fiat debt has value in an economy, the government can finance permanently higher deficits by implicitly taxing (depreciating the value of) its outstanding stock of that debt.

\section{The Budget Constraint}

The concepts of deficit policies, fiat debt, and implicit taxation and the proposition that higher deficit policies lead to higher inflation can be explained more precisely by referring to a formal representation (in equation form) of the limits faced by a federal government and a central bank (like the Federal Reserve) trying to finance a budget deficit. I will derive the consolidated federal government-central bank budget constraint assuming that the government borrows by selling fiat bonds which are discounts issued for one period. The government sells the bonds in an open market at a price below their face value (par) and retires all outstanding privately held bonds at par. The difference between par and market price (the discount) represents interest. The bonds which are not purchased by the private sector are purchased by the central bank by creating money: currency and bank reserves. Because the money is backed only by fiat bonds, it too is a form of fiat debt.

First I will derive separate period-by-period budget constraints for the federal government and the central bank and consolidate them. Then I will generate the consolidated budget constraint that must hold over time when the economy grows at a constant rate (so-called steady-state growth). This last step provides a shorthand way of examining long-run relationships. ${ }^{2}$

In current-dollar terms, the federal government's periodby-period budget constraint states that each period it must raise enough revenue from new bond sales to finance both debt service-the principal and interest payments on its privately held debt-and the deficit net of debt service. In algebraic form, the constraint says

$$
\text { Deficit }=\text { Net bond sales }
$$

where

$$
\begin{aligned}
\text { Net bond sales }= & \text { Total sales of new bonds } \\
- & \text { Principal and interest payments } \\
& \text { to retire bonds previously sold to } \\
& \text { the private sector. }
\end{aligned}
$$

Introducing symbols that distinguish prices and quantities lets me write this constraint as

$$
P(G-T)=P^{B} B^{*}-B_{-1}
$$

where

$$
\begin{aligned}
P= & \text { general price level } \\
G= & \text { real government expenditures } \\
& \text { (net of debt service) } \\
T= & \text { real government tax receipts } \\
G-T= & \text { real government deficit } \\
P(G-T)= & \text { current-dollar government deficit } \\
B^{*}= & \text { total stock of government bonds sold in } \\
& \text { the current period } \\
B_{-1}= & \text { stock of privately held government } \\
& \text { bonds sold in the previous period } \\
P^{B}= & \text { price of government bonds when issued, } \\
& \text { defined to be } 1 /(1+R), \text { where } R \text { is the } \\
& \text { nominal one-period interest rate. }
\end{aligned}
$$

\footnotetext{
${ }^{2}$ In general, a persistent deficit policy is feasible when the present value of real government expenditures does not exceed the present value of real government revenues defined to include both explicit and implicit taxes. The steadystate assumptions provide a way of looking at these present-value relationships for a smoothly growing economy.
} 
According to (1), the federal government sells $B^{*}$ bonds on the open market but retires only its bonds purchased by the private sector $B_{-1}$. The difference between total bonds sold and bonds sold to the private sector consists of bonds sold to the central bank. Again, the central bank pays for its bond purchases by creating money which ends up in the private sector. Because the central bank simply accumulates bonds in its portfolio rather than presenting the maturing bonds for payment, the central bank's period-by-period budget constraint is simply

Central bank bond purchases $=$ Money created or, in the symbolic notation just introduced,

$$
P^{B}\left(B^{*}-B\right)=M-M_{-1}
$$

where

$$
\begin{aligned}
M= & \text { stock of money } \\
P^{B}\left(B^{*}-B\right)= & \text { value of bonds purchased by the } \\
& \text { central bank (total less value } \\
& \text { purchased by the private sector) } \\
M-M_{-1}= & \text { increase in the money stock. }
\end{aligned}
$$

The consolidated federal government-central bank period-by-period budget constraint is found by combining the two institutions' budget constraints to get

Deficit $=$ Money created + Net private bond sales

or

$$
P(G-T)=\left(M-M_{-1}\right)+\left(P^{B} B-B_{-1}\right) .
$$

This constraint states that the government's current-dollar deficit is financed by the increase in values of its money and bonds held in the private sector.

To examine how the federal government can finance a permanent deficit, we cannot just look at the period-byperiod budget constraint. Instead we must examine all current and future deficits and their means of finance to determine if the government will be able to finance the permanent deficits without ever becoming insolvent. For my purposes, which abstract from the cyclical fluctuations of the economy and focus on the effects of persistent or permanent shifts in budget policy, it is enough to consider a representative fiscal period in an economy growing smoothly over time, a steady-state economy, and derive the consolidated budget constraint assuming perfectly smooth, or constant, growth in real output.

To derive this constraint from the period-by-period version, I first divide all terms in (3) by $P X$, where $X$ is the rate of real output. Then I impose the steady-state real growth conditions -that for all time periods

$$
\begin{aligned}
& G_{t} / X_{t}=\tilde{G} \quad \text { Real government } \\
& \text { expenditures are a constant } \\
& \text { proportion of real output. } \\
& T_{t} / X_{t}=\tilde{T} \\
& X_{t} / X_{t-1}=1+\nu \quad \text { Real output grows at the } \\
& \text { constant rate } \nu \text {. } \\
& P_{t} / P_{t-1}=1+\Pi \quad \text { Prices grow at the constant } \\
& \text { rate } \Pi \text {. } \\
& P^{B}=1 /(1+R) \quad \text { The nominal interest rate is } \\
& \text { constant. } \\
& M / P X=\tilde{M}^{d}(R, \Pi) \quad \text { The real, per unit of output, }
\end{aligned}
$$

Making these substitutions in (3) divided by $P X$ yields, finally, the consolidated federal government-central bank steady-state budget constraint for a representative fiscal period:

$$
\begin{aligned}
& \tilde{G}-\tilde{T}=\{1-[1 /(1+\Pi)(1+\nu)]\} \tilde{M}^{d}(R, \Pi) \\
& +\{1-[(1+R) /(1+\Pi)(1+\nu)]\} \tilde{B}^{d}(R, \Pi) .
\end{aligned}
$$

The budget constraint in this form demonstrates the importance of fiat debt to a government that wants to persistently run deficits. According to (4), a persistent deficit policy $(\tilde{G}-\tilde{T}>0)$ is feasible if the real deficit does 
not exceed the real revenue the government can extract from its money and bond issue (that is, from depreciating the value of its fiat debt). The terms in braces determine the government's tax take from money and bond issue. The tax bases for the two taxes are real private holdings of money and bonds, $M / P$ and $P^{B} B / P$, respectively. The tax bases both grow smoothly at the rate $\nu$. With no growth in the tax base, $\nu=0$, the terms in the braces can be considered the implicit tax rates on real money and real bond holdings.

Some insights are gained about those tax rates by setting $\nu=0$ and applying a little algebra. The implicit tax rate on money, $\{1-[1 /(1+\Pi)]\}$, is positive as long as the rate of inflation is positive $(\Pi>0)$. The implicit tax rate on bonds, $\{1-[(1+R) /(1+\Pi)]\}$, is positive as long as the real rate of interest is negative $(R-\Pi<0)$. Money and bond issue provide the government with positive tax takes as long as the terms in braces are positive, and that requires for each that the sum of the implicit tax rate and the growth in the tax base is positive. ${ }^{3}$ Only when the demands for fiat money and bonds and the implicit tax takes on them are positive can a permanent deficit be financed.

\section{Clarifications}

The proposition that higher deficit policies lead to higher inflation can be stated more precisely now as " a permanent increase in $\tilde{G}-\tilde{T}$ requires an increase in $\Pi$ in order for budget constraint (4) to be satisfied." 'In order to properly interpret " a permanent increase in $\tilde{G}-\tilde{T}$ " " when testing the proposition with actual data, it is helpful to recall the definitions and assumptions used in the construction of (4). Two points are worth emphasizing.

One is that a sustained increase in $\tilde{G}-\tilde{T}$ must be interpreted as a policy-induced increase in the deficit, that is, as a change in expenditure programs or tax rates which raises the deficit permanently for a given path of the economy. It does not refer to an increase in deficits caused by a cyclical downturn in the economy. Cyclical deficits are by definition temporary; they diminish as the economy recovers. To be consistent with this interpretation, the budget constraint (4) is derived under the assumption of steady real growth, not cycles of ups and downs.

This distinction between policy-induced and cyclical deficits is crucial because my argument does not claim that cyclical deficits are inflationary. An increase in the reported deficit could well be associated with lower inflation when both changes are caused by a weakening in economic conditions. Thus, the measure $\tilde{G}-\tilde{T}$ that I am considering is not the reported deficit, relative to reported real GNP, but is instead the real deficit net of debt service which would occur assuming trend real GNP, relative to trend real GNP.

The other point worth emphasizing is that a sustained increase in $\tilde{G}-\tilde{T}$ must be interpreted as a policy change for a government that can issue fiat debt, debt not backed by anything. If debt issued today were assumed to be backed, for example, by higher explicit taxes in the future, then an increase in $\tilde{G}-\tilde{T}$ could not be sustained over time; a higher $\tilde{G}-\tilde{T}$ today would imply a lower $\tilde{G}-\tilde{T}$ in the future. Nor can the debt be backed by real goods. If the government issued bonds to purchase capital goods, its period-byperiod budget constraint would be different from (1). Since the government then could always sell its capital to finance expenditures, the change in the current value of its capital stock would have to be included in (1). Or, if money were backed by a commodity like gold, the central bank's period-by-period budget constraint would be different from (2). The central bank could not always issue money to buy unbacked government bonds; its money issue would be constrained by its holdings of gold, and the value of gold would show up in its budget constraint. The consolidated federal government-central bank budget constraints (3) and (4), then, are based on the assumption that the consolidated balance sheet has privately held money and bonds on the liability side but no capital goods on the asset side, which makes both money and bonds forms of fiat debt.

\section{Why Higher Deficit Policies Increase Inflation}

While the government's budget constraint is useful in showing how a permanent deficit might be financed and in clarifying what is meant by "higher deficit policies lead to higher inflation," it cannot determine whether that proposition is true. In order to determine whether a higher deficit policy can, in fact, be financed and, if it can, whether it will lead to higher inflation, a theory of the economy and monetary system is required.

\section{The Legal Restrictions Theory}

When the government issues fiat debt, budget policy determines the total amount of debt [by (1)], while monetary policy determines its distribution between fiat money and fiat bonds [by (2)]. The supplies of these assets together with the aggregate demands $\tilde{M}^{d}$ and $\tilde{B}^{d}$ determine the rate of inflation $\Pi$ and the nominal interest rate $R$. In order

\footnotetext{
${ }^{3}$ The condition for money is $\Pi+\nu>0$, or simply $\Pi>-\nu$. The condition for bonds is $\Pi-R+\nu>0$, or simply $R-\Pi<\nu$. Both of these conditions for positive taxes are approximations found by setting $\Pi \nu=0$. The approximations would be exact in continuous time.
} 
to determine the relative roles of monetary and budget policies in affecting inflation and interest rates, however, we need a theory of the economy and monetary system to describe the nature of $\tilde{M}^{d}$ and $\tilde{B}^{d}$.

The budget constraint indicates that at least one of the demands $\tilde{M}^{d}$ or $\tilde{B}^{d}$ must be positive if higher deficits are to be feasible. So the theory of the demands for money and government bonds should include an explanation of why people would value either of them. Valued fiat debt is by no means assured. When private markets exist for making all possible types of trades (when markets are complete), fiat money and bonds are of no use either as goods (they are not physically consumed or used in production) or as assets (they do not expand the trades that can be made), and the private sector has no demand for them. Or, in an unrestricted economy, when assets exist which have rates of return in all states of the economy that exceed the rates of return on fiat debt, the demands for fiat debt will be zero. In these cases, according to (4), persistent deficit policies simply cannot be financed.

Although positive demands for fiat debt are not assured, governments can enact laws and regulations to assure them. And they do. In the United States, for example, fiat debt has value in part because of such government rules as legal tender laws and reserve requirements. These laws and regulations force individuals and depository institutions to demand government fiat debt even when it is being taxed, and this allows persistent deficits to be financed.

The laws and regulations a government enacts not only assure the demands for its fiat debt; they also separate the demands for money and bonds. U.S. depository institutions, for instance, are not only required to hold in reserve a proportion of their deposits in the form of fiat debt (which increases the total demand for such debt). That fiat debt is further specified to be in the form of money, not bonds (which separates the demands for money and bonds). Institutions also are prevented by law from issuing bearer notes backed by government bonds (which, along with the large denominations of bonds, also separates the demands for money and bonds). ${ }^{4}$

Without laws and regulations, if fiat money and bonds were held at all, they would become perfect substitutes; the distinction between them would disappear (Wallace 1979). To see why that is so, suppose that money and bonds were issued in the same denominations and that the government in no way restricted or regulated the use of either instrument. Both assets would then be held only if they paid the same rate of return. If an $n$-period bond paid a positive interest rate while money didn't, for instance, a trader could profit by breaking the bond into $n$ one-period bonds, each paying a positive rate of return. Everyone would then prefer one-period bonds to money, and no one would hold money. Thus, without legal restrictions, the demand for fiat debt could fall to zero, and if it didn't, bonds and money would become perfect substitutes, leaving the government with only one implicit tax rate.

If money and bonds were perfect substitutes, deficits would be directly inflationary, and monetary policy would be irrelevant. That is because budget policy would determine the growth of total fiat debt, while monetary policy would determine the distribution of fiat debt between two perfect substitutes. So without the laws and regulations that enhance and separate the demands for fiat debt, the government would have an unassured base for its implicit taxesone or both of the types of debt might not be demandedand its steady-state implicit tax rates on money and bonds would be equal.

A purpose behind these laws and regulations, then, may be to allow the government to raise its implicit taxes more efficiently. By increasing the demands for fiat debt, they increase the tax base for implicit taxes and so allow a given amount of revenue to be raised at lower implicit tax rates. By assuring two distinct debt instruments yielding different returns, they allow the government to tax-discriminate in financing deficits. ${ }^{5}$ [This occurs whenever nominal interest rates on government bonds are positive, for then, according to (4), the implicit tax rate on money is higher than the implicit tax rate on bonds.]

\section{Three Channels for Inflation}

This legal restrictions theory of fiat money and fiat bonds can generate a model which has some properties common to monetarist models which deny the influence of deficits on inflation: money growth as the immediate cause of inflation, a one-for-one relationship between changes in inflation and changes in nominal interest rates, and expansiveness of open market purchases (Miller 1982a,b). These properties result when the restrictions cause money to cir-

\footnotetext{
${ }^{4}$ For a discussion of how this last restriction works, see Neil Wallace's paper, "A Legal Restrictions Theory of the Demand for 'Money' and the Role of Monetary Policy," in this Quarterly Review.

${ }^{5}$ It might also be argued that restrictions having the effect of separating demands for money and bonds were imposed so that the government could control the stock of money to pursue a price stabilization goal and control the stock of bonds to smooth tax rates over time. This tax discrimination rationale for legal restrictions was first worked out in Bryant and Wallace 1980 and was employed in Miller 1982a,b,c.
} 
culate as a medium of exchange, while bonds compete with capital as a store of value. However, when the separation of demands formoney and bonds is due to government restrictions, higher deficits lead to more inflation, in three ways: monetary accommodation, crowding out, and private monetization of government debt. ${ }^{6}$

Monetarists commonly acknowledge that higher deficits lead to more inflation when the Federal Reserve accommodates by monetizing the deficits. But these economists tend to view the Fed's accommodation either as a lack of resolve or as shortsightedness (Friedman 1981a, Hein 1981, Weintraub 1981). This view implies that more inflation is avoidable if the Fed acts responsibly. The restrictions theory, however, suggests that the Fed may have little choice.

A key implication of the theory of financial restrictions is that federal budget and monetary policies must be coordinated (Sargent and Wallace 1981; Miller 1982a,b). In fact, if deficits are financed efficiently (that is, with minimal distortion of private sector incentives and behavior), it is not feasible to finance larger deficits-even temporary onesby bond issue alone (Miller 1982c). Larger deficits require accommodation by the monetary authority; if it is not forthcoming, the increase in bonds will cause real interest payments on bonds to grow without limit, thereby forcing the government into insolvency. Central bank monetization of deficits-and more inflation-is, then, necessary at some point to prevent the insolvency. ${ }^{7}$

The need to monetize deficits in order to prevent insolvency can be viewed another way. If the central bank ignores budget policy and sticks to a predetermined path of money-say, a no-growth path-then the federal government is denied the option of creating money to finance deficits. Additional bond issue becomes like that of state and local governments: it must be backed by higher revenue in the future. Trying to service the bonds by issuing new bonds only causes the interest on the debt and, thus, total debt to snowball.

Crowding out is another way that, under the legal restrictions theory, higher deficits lead to more inflation. Different degrees of monetary accommodation are feasible for a given increase in deficits. Less monetary accommodation requires more bonds to be sold on the open market to private investors, and in general this drives more private capital out of the market. That is because bonds compete with private capital in individual portfolios. When there are decreasing returns to capital, the substitution of government current expenditures for private capital expenditures raises the real rate of interest and lowers the path of real output (Friedman 1981b, Miller 1982c). A given money path combined with a lower output path produces a higher price path.

Finally, the legal restrictions theory implies that higher deficits lead to more inflation by encouraging the private sector to circumvent the restrictions on bonds and so, in effect, to privately monetize government debt. A plausible explanation of how this happens is the following. Suppose the legal restrictions can be circumvented by private intermediaries in successive steps only at successively higher costs. The profit from finding ways around the restrictions is the difference between those increasing costs and the revenue that can be earned by substituting bond holdings for money holdings. This profit, then, is related directly to the difference in returns on bonds and money: the nominal interest rate.

When a policy of higher deficits raises interest rates, therefore, the private sector responds by pursuing more ways to circumvent the restrictions on substituting bonds for money. Private intermediaries find it profitable, for example, to develop financial instruments backed by government bonds, which the private sector can use in lieu of money and which earn interest at something less than the government bond rate. As a result, bonds become easier to use for spending, and that implies more inflation for given deficits and money growth. In terms of the budget constraint, as the private sector finds ways to shift its fiat debt holdings from highly taxed money to less highly taxed bonds, total implicit taxes fall. For a given increase in deficits, the government can only offset these losses if inflation increases and so raises the implicit tax rates on money and bonds.

Casual observation suggests that this third way higher

\footnotetext{
${ }^{6}$ Strictly speaking, more inflation will result through these channels provided the private sector's demands for fiat money and bonds do not increase. It is assumed in what follows that the government does not raise these demands by tightening restrictions (for example, by raising reserve requirements). It seems reasonable that, if an increase in implicit taxes on fiat debt were required, the increase could be levied by some combination of tighter regulations (an increase in the base) and higher inflation (an increase in the tax rate).

Under a transaction cost theory of separate demands for money and bonds, higher deficits do not lead to higher inflation through monetary accommodation or crowding out. According to this theory, private monetization causes bonds to be almost perfect substitutes for money, so deficits are directly inflationary. (See Bryant and Wallace 1979.)

${ }^{7}$ Deficits also can be so large that insolvency will not be avoided even with monetary accommodation. Higher inflation drives the implicit tax rates on fiat debt toward one (as the budget constraint makes clear) but lowers the demand for fiat debt. Hence, the implicit taxes that can be raised through monetary accommodation and its resulting inflation are bounded.
} 
deficits lead to inflation under the legal restrictions theory is more than a theoretical possibility. In recent years in the United States there have developed, at money market mutual funds, demand deposit accounts that are backed by Treasury securities and, at banks, deep-discount insured certificates of deposit that are backed by Treasury securities, issued in denominations of as little as $\$ 250$, and assured of purchase by a broker (Sloane 1982). In Brazil, which has run high deficits for years, Treasury bills have become very liquid: their average turnover is now less than two days.

\section{What Has Actually Happened}

Despite many claims to the contrary, evidence does suggest that higher inflation results from higher deficit policies. Both U.S. and international experiences suggest it. The reason that many studies fail to detect any relationship is that they fail to distinguish between deficit policies and deficit realizations.

\section{Proper and Improper Tests}

In order to clarify the statistical issue, I posit a simple time series model to serve as a frame of reference. The model is motivated by the theory described in the previous section and can be easily generalized to allow, for example, longer lags. The main difference between this and the earlier discussion is that here I do not construct the model for the steady state. Its long-run properties thus are not immediately apparent but instead must be derived.

The state of the economy at time $t$ is described by the rate of real output $X_{t}$, the aggregate price level $P_{t}$, and the nominal interest rate on one-period bonds $R_{t}$. Policy instruments include total unbacked federal debt $B_{t}^{*}$ and unbacked money-the value of $B^{*}$ purchased by the monetary authority $-M_{t}$. Budget policy (5) and monetary policy (6) are rules for determining current values of those instruments as linear functions (feedback rules) of the state of the economy and the policy instruments in the previous period:

$$
\begin{aligned}
B_{t}^{*}=a_{1}+b_{1} t & +c_{11} X_{t-1}+c_{12} P_{t-1}+c_{13} R_{t-1} \\
& +d_{11} B_{t-1}^{*}+d_{12} M_{t-1}+\epsilon_{1 t} \\
M_{t}=a_{2}+b_{2} t & +c_{21} X_{t-1}+c_{22} P_{t-1}+c_{23} R_{t-1} \\
& +d_{21} B_{t-1}^{*}+d_{22} M_{t-1}+\epsilon_{2 t}
\end{aligned}
$$

where the $a$ 's, $b$ 's, $c$ 's, and $d$ 's are coefficients and the $\epsilon$ 's are serially uncorrelated random disturbances. Policies are thus associated with numerical values of the coefficients in these feedback rules. The debt level $B_{t}^{*}$ and the money supply $M_{t}$ that actually occur in any period depend on the policy rules, the state of the economy and the policy instruments in the previous period, and the random disturbances.

The economic process describes how the current state of the economy is determined by its own past values and the past and previously expected current values of the policy instruments:

$$
\begin{aligned}
X_{t}=f_{1}+g_{1} t & +h_{11} X_{t-1}+h_{12} P_{t-1}+h_{13} R_{t-1} \\
& +i_{11} B_{t-1}^{*}+i_{12} M_{t-1}+j_{11} E_{t} B_{t}^{*} \\
& +j_{12} E_{t} M_{t}+\mu_{1 t} \\
P_{t}=f_{2}+g_{2} t & +h_{21} X_{t-1}+h_{22} P_{t-1}+h_{23} R_{t-1} \\
& +i_{21} B_{t-1}^{*}+i_{22} M_{t-1}+j_{21} E_{t} B_{t}^{*} \\
& +j_{22} E_{t} M_{t}+\mu_{2 t} \\
R_{t}=f_{3}+g_{3} t & +h_{31} X_{t-1}+h_{32} P_{t-1}+h_{33} R_{t-1} \\
& +i_{31} B_{t-1}^{*}+i_{32} M_{t-1}+j_{31} E_{t} B_{t}^{*} \\
& +j_{32} E_{t} M_{t}+\mu_{3 t}
\end{aligned}
$$

where the $f$ 's, $g$ 's, $h$ 's, $i$ 's, and $j$ 's are coefficients; the $\mu$ 's are serially uncorrelated random disturbances; and $E_{t} B_{t}^{*}$ and $E_{t} M_{t}$ are people's expectations of the current levels of debt and money, respectively, conditional on known values of the state of the economy and the policy instruments at time $t-1$. The $j$ coefficients play the important role of representing how the current state of the economy is affected by people's expectations of policy instrument values. I assume that those expectations are rational, that is, consistent with the forecasts that would be generated by the model-here, the policy rules (5) and (6).

Because the expectations terms cannot be directly observed, the coefficients of the economic process (7)-(9) cannot be statistically estimated. Replacing the unobserved expectations with the objective forecasts based on the policy rules (5) and (6) produces an estimable system with each equation analogous to the following one for the price level:

$$
\begin{aligned}
P_{t}=\alpha+\beta t & +\gamma_{1} X_{t-1}+\gamma_{2} P_{t-1}+\gamma_{3} R_{t-1} \\
& +\delta_{1} B_{t-1}^{*}+\delta_{2} M_{t-1}+\mu_{2 t}
\end{aligned}
$$

where 


$$
\begin{aligned}
& \alpha=f_{2}+j_{21} a_{1}+j_{22} a_{2} \\
& \beta=g_{2}+j_{21} b_{1}+j_{22} b_{2} \\
& \gamma_{1}=h_{21}+j_{21} c_{11}+j_{22} c_{21} \\
& \gamma_{2}=h_{22}+j_{21} c_{12}+j_{22} c_{22} \\
& \gamma_{3}=h_{23}+j_{21} c_{13}+j_{22} c_{23} \\
& \delta_{1}=i_{21}+j_{21} d_{11}+j_{22} d_{21} \\
& \delta_{2}=i_{22}+j_{21} d_{12}+j_{22} d_{22} .
\end{aligned}
$$

The coefficients of the estimable system, of which (10) is an example, are combinations of the coefficients of policies (5) and (6) and coefficients of the economic process (7), (8), and (9). The coefficients of the policies-the $a$ 's, $b$ 's, $c$ 's, and $d$ 's-appear in the estimable system because of the assumptions that the current state of the economy depends on people's expectations of policy (not all the $j$ 's are zero) and that those expectations incorporate information about the policies actually in place.

The empirical counterpart of the proposition that higher deficit policies lead to higher inflation now can be restated in terms of (5) and (10) as "an increase in $a_{1}$ or $b_{1}-\mathrm{a}$ constant or growing increase in deficits-leads to an increase in $\alpha$ or $\beta-$ a constant or growing increase in the price level $P_{t},{ }^{, 8}$ If the model (5)-(9) is correct, the proposition is true when people's expectations of deficits incorporate information about the actual policy rule (5) (expectations are rational) and when those expectations are positively related to inflation $\left(j_{21}>0\right)$. Since economists who argue that deficits are not inflationary generally accept the rational expectations assumption, the controversial part of the proposition is the required relationship between expectations and inflation, that $j_{21}>0$.

In order to determine whether or not $j_{21}$ is positive, it is necessary to empirically estimate the coefficients of a system of equations which includes at least (5) and (10). A shift in budget policy (5) must be detected, and estimates of the coefficients of (10) must be made before and after the policy shift. In order to have reliable estimates, there should be many such policy shifts.

Examining studies which find no inflationary effects of deficit policies in the context of system (5)-(10) reveals why those studies are flawed. They attempt to estimate the coefficient on deficits in a price equation $\left[\delta_{1}\right.$ in (10) $]$ and test the proposition that higher deficits increase inflation by examining whether that coefficient is significantly positive.
(See, for example, Blinder 1982, Hein 1981, Perry 1978, Stein 1976, and Weintraub 1981.) In order for this estimation technique to be valid, the relationship of prices to the other variables must not change over the period of estimation, but according to the model (5)-(9), that assumption is valid only if the deficit policy (5) doesn't change.

Thus, studies done in the standard way offer little evidence about whether higher deficit policies lead to higher inflation. If the assumptions underlying their estimation technique are valid, then deficit policy did not change during the estimation period and these studies can offer no evidence about the effects of such a change. They at best can detect the relationship between deficit realizations and inflation under a given policy $\left(\delta_{1}\right)$, and as my model (5)-(9) suggests, this relationship can be of any sign or magnitude. In more intuitive terms, the standard studies pick up how deficits and inflation were related over the business cycle under a given policy, and that relationship can be anything . However, if policy did change during the estimation period, then the assumptions underlying the estimation technique in standard studies are violated and theirestimates are not valid. The coefficients in (10) cannot be expected to remain invariant under different policies.

\section{Evidence From Studies of Deficit Policy Changes}

Persuasive evidence that higher deficit policies lead to more inflation comes from studies of dramatic budget policy changes in countries around the world. For example, Sargent's (1981) study strongly suggests that the European hyperinflations of the 1920 s were fueled by policies of high deficits and unbacked debt and were abruptly halted when policies of balanced budgets and backed debt were reinstated. Harberger (1982) and McKinnon (1982), in their separate studies of Chile and of Argentina and Chile, respectively, document the pivotal role played by budget policies in determining those countries' inflation outcomes. Patinkin (1979) describes a similar experience for Israel.

The evidence for the modern U.S. economy cannot be as strong. This is because, in post-World War II history through 1981, there seems to have been only one major shift in federal budget policy-a shift in the late 1960s from nearly balanced budgets to persistent deficits - and that shift

\footnotetext{
${ }^{8} \mathrm{An}$ increase in $a_{1}$ or $\dot{b}_{1}$ implies an increase in deficits for given economic conditions, the type of increase considered in the previous sections. In a strict sense, an increase in $a_{1}$ or $b_{1}$ implies, respectively, a constant or growing increase in deficits only when $d_{11}=1$. A change in any of the $c$ 's need not change the average size of deficits; it might only change the responsiveness of deficits to changes in economic conditions.
} 
does not seem to have been large compared to the examples cited above. To determine whether that apparent shift to a policy of higher deficits was statistically significant and to examine the shift's impact on inflation, I estimate over the period 1948-81 a vector autoregressive model (VAR) [a version of (5), (6), and equations like (10)], test for a significant change in budget policy (5), and estimate separate models for the period before and the period after the change (Miller 1982d).

Because there is only one shift in U.S. budget policy to examine, a finding of higher inflation in the period of higher deficits would be very weak evidence for the proposition: many other changes (besides policy changes) in the two periods could account for inflation being higher when deficits were. So, in an attempt to judge the proposition more conclusively, I also test some other implications of the legal restrictions theory which generates the proposition. The theory suggests that, in the period of higher deficits, along with inflation being higher, fiat bonds should be more like fiat money and less fiat money should be held for any given level of GNP. If the legal restrictions theory is correct,

\section{Chart 1}

\section{Along with a higher deficit policy came higher inflation.}

Average Annual Rates of Growth in Federal Debt and the GNP Deflator During 1948-66 and 1967-81

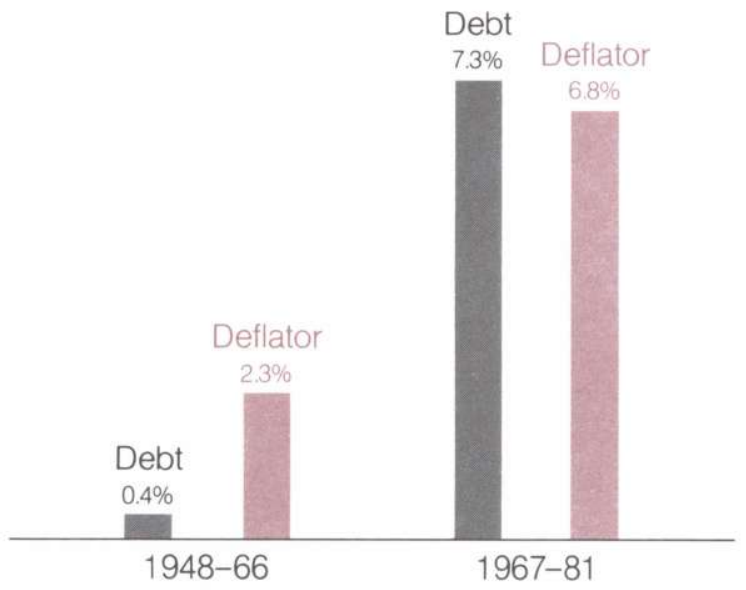

Source: U.S. Department of Commerce bonds become more like money as people develop ways to circumvent the restrictions separating the demands for money and bonds, and less fiat money is held for a given level of GNP (its velocity, GNP/ $M$, rises) as fiat bonds take on some functions formerly served by money. If these other implications are supported by the U.S. data, then that corroborates, and strengthens, any direct evidence supporting the proposition.

The VARs I examine contain five quarterly time series: a measure of real output, real GNP (RGNP); a measure of the price level, the GNP deflator (GNPD); a representative market interest rate, the 90-day Treasury bill rate (RTB); a measure of fiat money, total bank reserves (TR); and a measure of total fiat debt, federal debt (DEBT). The measure of fiat money is the St. Louis Federal Reserve Bank's "total reserves" series, adjusted for seasonal factors and changes in reserve requirements. It is intended as a measure of the unbacked money that the private sector would have held if there had been no changes in financial restrictions. The measure of fiat debt is constructed by adding the accumulated, quarterly national income account deficit (not annualized) to the total public debt net of government account holdings in 1948. In the VARs, all series except the bill rate are logged.

This limited set of variables is intended to be the smallest system able to capture major channels of policy influence: monetary and budget policies together determine the inflation rate and the interest rate, which in turn affect real output by their impact on the rate of investment. Monetary policies and budget policies are represented as rules which determine the current levels of bank reserves and federal debt, respectively, as functions of lagged values of all the variables in the system.

Each variable in the system is regressed on a constant and on $m$ lags of all five variables. Thus, the system can be written as

$$
Y_{t}=C+\sum_{i=1}^{m} A_{i} Y_{t-i}+\lambda_{t}
$$

where

$$
Y \equiv\left[\begin{array}{l}
\ln (\mathrm{RGNP}) \\
\ln (\mathrm{GNPD}) \\
\mathrm{RTB} \\
\ln (\mathrm{DEBT}) \\
\ln (\mathrm{TR})
\end{array}\right]
$$


Charts 2 and 3

\section{After the shift to a higher deficit policy, bonds seemed to explain at least as much of inflation's changes as money did. . .}

Percentages of the Forecast Variance of the GNP Deflator Caused by Unexpected Changes (Innovations) in Federal Debt(Bonds) and Total Reserves (Money) According to Models Based on Data for 1948-66 and 1967-81
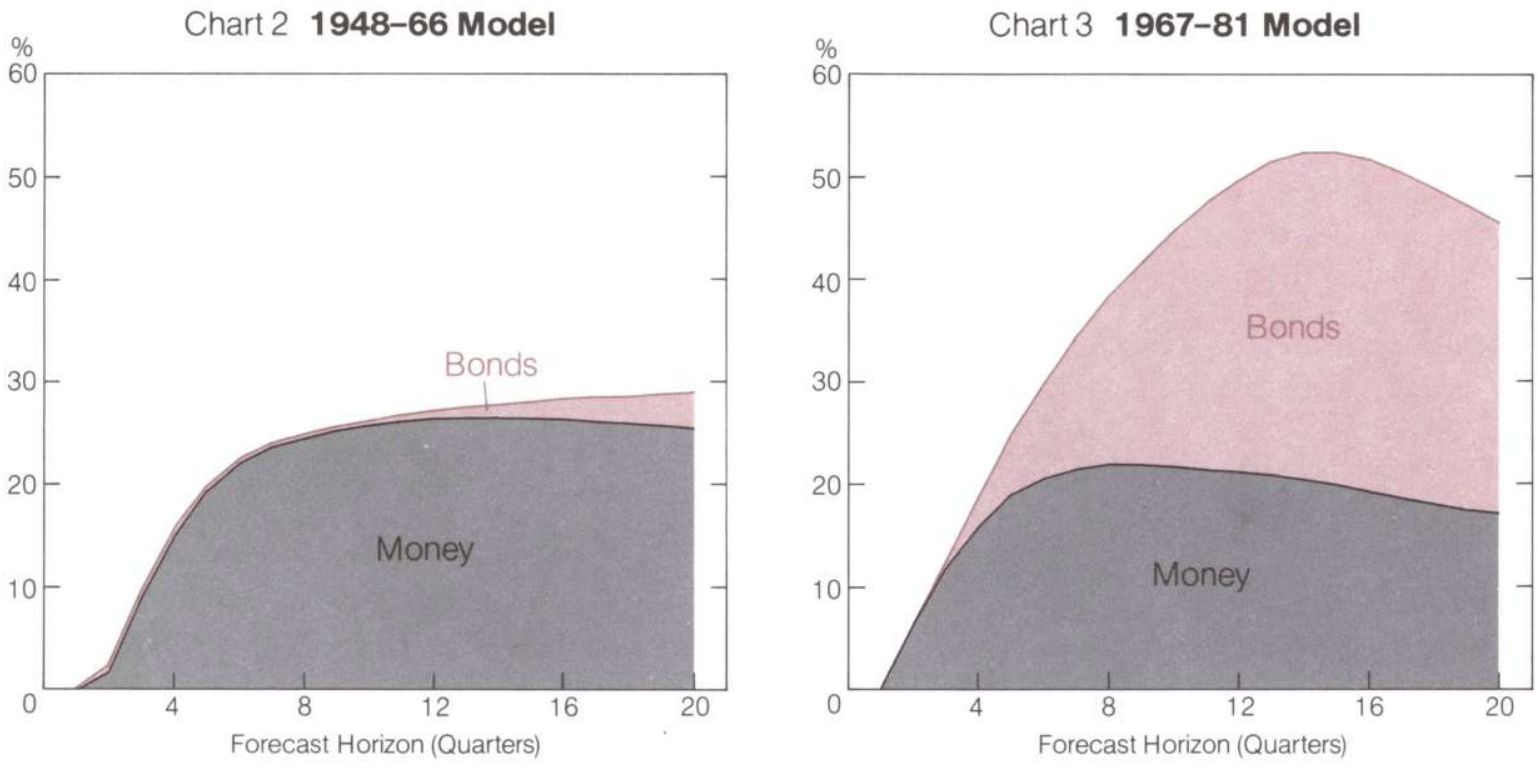

Sources of basic data: U.S. Department of Comn!erce; Federal Reserve Bank of St. Louis

$$
\lambda \equiv\left[\begin{array}{c}
\lambda_{1} \\
\cdot \\
\cdot \\
\cdot \\
\lambda_{5}
\end{array}\right]
$$

$C$ and $A_{i}$ are $5 \times 1$ and $5 \times 5$ matrices of coefficients, respectively, and $m=$ lag length. The coefficients in the matrices $C$ and $A_{i}$ are estimated by ordinary least squares, and $E \lambda \lambda^{\prime}$ $=\Lambda$ is estimated by the variance-covariance matrix of residuals.

For the test for a change in budget policy, I divide the entire postwar period into two subperiods: from 1948:1 to 1966:4, when budgets were nearly balanced, and from 1967:1 to $1981: 4$, when budgets were almost constantly in deficit. To test whether the change in budget policy is statistically significant, I determine the probability that the residuals from the two subperiod DEBT regressions were drawn from the same distribution. The probabilities are determined for lag lengths $m=1$ through 8 . For all lag lengths except 8 , the probability that the residuals were drawn from the same distribution is less than 5 percent (and for lag length 8 it is only 7 percent). Since the DEBT equation reflects the budget policy, this result means that one can state with a high degree of confidence that deficit policies were different in the two subperiods.

The proposition that higher deficits lead to higher inflation can be directly examined without employing other equations of the VARs. And the data do support it. (See Chart 1.) Between the two subperiods, the average annual growth rate of federal debt shot up from only about half a percent to nearly 7.5 percent. At the same time, inflation 
clearly increased: The average annual growth rate of the GNP deflator roughly tripled between the two subperiods.

We can also easily examine one of the possibly corroborating implications of the legal restrictions theory-that the velocity of fiat money should grow faster when deficits are higher. And this too is supported by the data. The average annual growth rate of total reserve velocity increased between the two subperiods, from 3.1 percent in the first to 3.9 percent in the second.

Testing the other corroborating implication of the restrictions theory, that bonds should become more like money in the period of higher deficits, does require the use of all equations in the VARs. Again, if the theory is correct, then in the second subperiod the response of the economic process, especially inflation, to an increase in total federal debt should have changed and changed in a way to make it close to the response to a comparable increase in money. In order to examine this implication, I estimate VARs of lag length 3 over each subperiod and then study the effects of money and bonds on inflation from two different perspectives.

Charts 2 and 3 show that bonds did indeed become more like money in their contribution to the forecast variance of the GNP deflator. The charts show cumulated parts of the decomposition of variance of the GNP deflator according to the VARs estimated over each subperiod. The parts are the proportions of the forecast variance in the GNP deflator which are attributable to innovations in bonds and money (DEBT and TR). Loosely speaking, the charts show how much of the parts of the GNP deflator which could not be predicted ahead is due to DEBT and TR being different from expected. In the first subperiod, for forecasts of ten quarters and more ahead, TR accounted for about 25 percent of the forecast variance of the GNP deflator, while DEBT accounted for almost none (Chart 2). However, for those forecasts in the second subperiod-when deficits and inflation both increased-TR and DEBT accounted for similar percentages of the GNP deflator's forecast variance, with DEBT actually accounting for slightly more than TR (Chart 3).

Charts 4 and 5 illustrate a similar result for the response over time of the GNP deflator to standardized shocks in bonds and money, according to the VARs estimated over each subperiod. In the first subperiod, the two shocks produced quite different reactions in the deflator: an unexpected increase in DEBT was correlated with a decline in the deflator from its expected level for about eight quarters, followed by increases thereafter; an unexpected increase in

\section{Charts 4 and 5}

\section{... .and bonds' impact on inflation over time closely resembled money's.}

Responses of the GNP Deflator to Unexpected Increases in Federal Debt (Bonds) and Total Reserves (Money)* According to Models Based on Data for 1948-66 and 1967-81
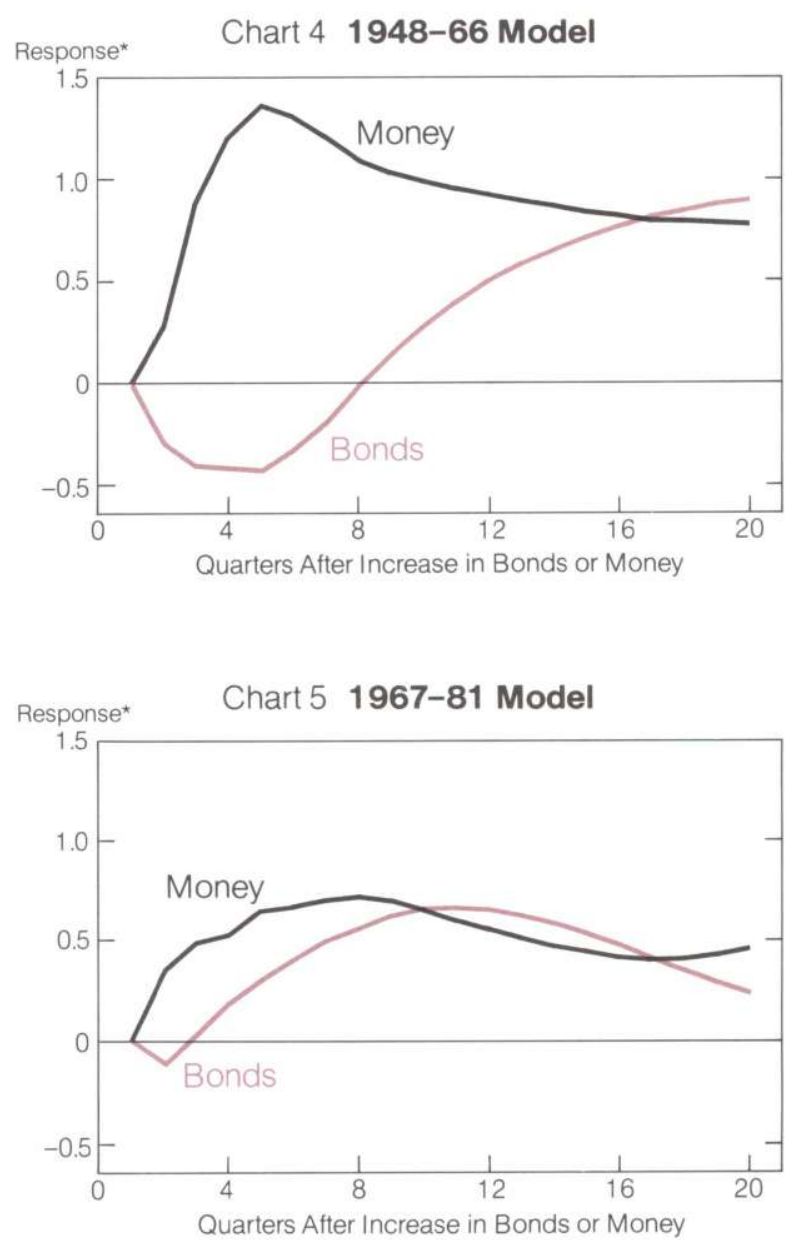

*The response of the GNP deflator to standardized positive shocks in DEBT and TR is measured in terms of the standard error of the forecast of GNPD.

Sources of basic data: U.S. Department of Commerce; Federal Reserve Bank of St. Louis 
TR was correlated with an immediate and sustained increase in the deflator(Chart 4). In the second, higher deficit subperiod, though, the dynamic responses of the deflator to positive shocks in DEBT and TR were very similar: after both shocks, the deflator increased almost immediately, the effect grew for two or three years, and then it dissipated (Chart 5).

\section{Summary}

Theory suggests that deficits matter for inflation if deficits is interpreted to mean deficit policy. A persistently higher deficit policy can be financed in an economy with valued fiat debt, money and privately held unbacked bonds. In such an economy, deficits determine the growth of total fiat debt. If the demands for the two types of debt are separate, then persistently higher deficits lead to higher inflation through necessary monetary accommodation and crowding out.

Separateness of demands for the two types of debt is not natural. Government restrictions on the use of bonds cause them to be imperfect substitutes for money. Larger deficits increase interest rates, and, thus, private incentives to circumvent the restrictions. As the private sector breaks down the restrictions, bonds become easier to use in transactions, so more inflation results from the same monetary and budget policies.

Empirical evidence supports the proposition that higher deficit policies increase inflation. Studies of many countries document the inflationary effects of deficit policies, including my study of the United States. The evidence for this country may not yet be as persuasive as that for others because of the minimal number and size of budget policy changes that have occurred. Unfortunately, we may have another and a larger change to investigate if current budget projections are realized.

\section{References}

Blinder, Alan S. 1982. On the monetization of deficits. Paper prepared for The Economic Consequences of Government Deficits: An Economic Policy Conference, cosponsored by the Center for the Study of American Business and the Institute of Banking and Financial Markets, held at Washington University, St. Louis, Missouri, October. Also forthcoming, in conference proceedings volume.

Bryant, John, and Wallace, Neil. 1979. The inefficiency of interest-bearing national debt. Journal of Political Economy 87 (April): 365-81.
1980. A suggestion for further simplifying the theory of money. Research Department Staff Report 62. Federal Reserve Bank of Minneapolis.

Friedman, Milton. 1981a. A memorandum to the Fed. Wall Street Journal (January 30 ).

1981b. Deficits and inflation. Newsweek (February 23): 70.

Grossman, Herschel I. 1982. The American fiscal deficit: Facts and effects, Working Paper 934. National Bureau of Economic Research.

Hamburger, Michael J., and Zwick, Burton. 1981. Deficits, money and inflation. Journal of Monetary Economics 7 (January): 141-50.

Harberger, Arnold C. 1982. The Chilean economy in the 1970s: Crisis, stabilization, liberalization, reform. In Economic policy in a world of change, ed. Karl Brunner and Allan H. Meltzer. Carnegie-Rochester Conference Series on Public Policy 17: 115-52. Amsterdam: North-Holland.

Hein, Scott E. 1981. Deficits and inflation. Review 63 (March): 3-10. Federal Reserve Bank of St. Louis.

McKinnon, Ronald I. 1982. The order of economic liberalization: Lessons from Chile and Argentina. In Economic policy in a world of change, ed. Karl Brunner and Allan H. Meltzer. Carnegie-Rochester Conference Series on Public Policy 17: 159-86. Amsterdam: North-Holland.

Miller, Preston J. 1982a. Fiscal policy in a monetarist model. Research Department Staff Report 67. Federal Reserve Bank of Minneapolis.

1982b. A monetarist approach to federal budget control. Research Department Working Paper 210. Federal Reserve Bank of Minneapolis.

1982c. Optimal crowding out in a monetarist model. Research Department Working Paper 212. Federal Reserve Bank of Minneapolis. 1982d. A time series analysis of federal budget policy. Research Department Working Paper 213. Federal Reserve Bank of Minneapolis.

Patinkin, Don. 1979. The inflationary experience: Some lessons from Israel. In Essays in post-Keynesian inflation, ed. James H. Gapinski and Charles E. Rockwood, pp. 125-34. Cambridge, Mass.: Ballinger.

Perry, George L. 1978. Slowing the wage-price spiral: The macroeconomic view. In Brookings Papers on Economic Activity, ed. Arthur M. Okun and George L. Perry, 2: 259-91. Washington, D.C.: Brookings Institution.

Sargent, Thomas J. 1981. The ends of four big inflations. Research Department Working Paper 158. Federal Reserve Bank of Minneapolis. Also 1982, in Inflation: Causes and effects, ed. Robert E. Hall, pp. 41-97. National Bureau of Economic Research Project Report. Chicago: University of Chicago Press.

Sargent, Thomas J., and Wallace, Neil. 1981. Some unpleasant monetarist arithmetic. Federal Reserve Bank of Minneapolis Quarterly Review 5 (Fall): 1-17.

Sloane, Leonard. 1982. Your money: Zero coupon, insured C.D.'s. New York Times (September 4): 20.

Sprinkel, Beryl. 1981. Testimony. In Conduct of monetary policy: Hearings before the Committee on Banking, Finance and Urban Affairs, House of Representatives, U.S. Congress, July 23, pp. 428-92. 97th Cong., 1st sess. Serial 97-17.

Stein, Jerome L. 1976. Inside the monetarist black box. In Monetarism, ed. Jerome L. Stein. Studies in Monetary Economics 1: 183-232. Amsterdam: North-Holland.

U.S. Congress. Congressional Budget Office (CBO). 1983. Baseline budget projections for fiscal years 1984-1988. Report to the Senate and House committees on the budget, February.

Wallace, Neil. 1979. Significant rate-of-return dominance: A proposed explanation in terms of legal restrictions. Unpublished paper, October.

Weintraub, Robert E. 1981. Deficits: Their impact on inflation and growth. Staff study prepared for the Subcommittee on Monetary and Fiscal Policy of the Joint Economic Committee, U.S. Congress. 97th Cong., 1st sess., July. 